\title{
UPLC-QTOF-MS Analysis of Extracts from the Leaves of Pouteria caimito (Sapotaceae) and Their Antioxidant Activity
}

\author{
Lorrayne Clemente Ribeiro de Sousa1, Almir Ribeiro de Carvalho Junior², \\ Mario Geraldo de Carvalho ${ }^{3}$, Tania Maria Sarmento da Silva ${ }^{4}$, Rafaela Oliveira Ferreira ${ }^{*}$ \\ ${ }^{1}$ Universidade Federal do Tocantins, Gurupi, Brazil \\ ${ }^{2}$ Instituto Federal de Santa Catarina, Criciúma, Brazil \\ ${ }^{3}$ Universidade Federal Rural do Rio de Janeiro, Seropédica, Brazil \\ ${ }^{4}$ Universidade Federal Rural de Pernambuco, Recife, Brazil \\ Email: *rafaellaoliveira@uft.edu.br
}

How to cite this paper: de Sousa, L.C.R., de Carvalho Junior, A.R., de Carvalho, M.G., da Silva, T.M.S. and Ferreira, R.O. (2019) UPLC-QTOF-MS Analysis of Extracts from the Leaves of Pouteria caimito (Sapotaceae) and Their Antioxidant Activity. Journal of Biosciences and Medicines, 7, 92-101.

https://doi.org/10.4236/jbm.2019.73009

Received: January 31, 2019

Accepted: March 22, 2019

Published: March 25, 2019

Copyright $\odot 2019$ by author(s) and Scientific Research Publishing Inc. This work is licensed under the Creative Commons Attribution International License (CC BY 4.0).

http://creativecommons.org/licenses/by/4.0/

\begin{abstract}
This study describes the phytochemical profile and antioxidant activity of an extract from the leaves of Pouteria caimito (Sapotaceae). The extract in ethanol was obtained by maceration at room temperature and subjected to the liquid-liquid partition to obtain fractions in hexane and ethyl acetate. Steroids, triterpenes, saponins, alkaloids and flavonoids were identified by the phytochemical prospection of extracts and fractions from the leaves. The analysis of the ethyl acetate fraction by UPLC-QTOF-MS allowed us to identify eight triterpenes, namely, euscaphic acid (1), hyptadienic acid (2), betulinic acid (3), oleanolic acid (4), ursolic acid (5), $3 \beta$-( $O$-p-coumaroyl)alphitolic acid (6), $3 \beta$-(O-p-coumaroyl)-maslinic acid (7) and $3 \beta$-( $O-p$-coumaroyl)-2-hydroxy-urs-12-en-28-oic acid (8). The ethanol extract and ethyl acetate fraction presented total phenolic contents of $10.6 \pm 0.1$ and $11.4 \pm 0.3$ mg GAE $\mathrm{g}^{-1}$, respectively, and considerable antioxidant activity in the DPPH assay with $\mathrm{EC}_{50}$ values of $299.4 \pm 1.5$ and $391.8 \pm 0.9 \mu \mathrm{g} \cdot \mathrm{ml}^{-1}$, respectively.
\end{abstract}

\section{Keywords}

Abiu, UPLC, Triterpenes, DPPH, Antioxidants

\section{Introduction}

The genus Pouteria Aublet is a pantropical group comprising nine sections and 325 species [1]. In Brazil, the centres of dispersion of the genus are mainly Amazonia and coastal regions, often occurring in Bahia, Espírito Santo, Rio de 
Janeiro and São Paulo [2]. The genus Pouteria is represented in Brazil by 114 species, of which 46 are endemic [3]. Many of these species produce high quality wood and edible fruits, such as $P$. caimito (abiu), $P$. macrocarpa (cutito), $P$. macrophyla (caimo) and P. sapota (sapota), which represent significant economic potential. In addition to their commercial importance, several species have been used in folk medicine to treat fevers, inflammations, ulcers, diabetes and nausea, among other applications [4] [5]. In addition, the extracts, semipurified fractions and isolated substances from the Pouteria species show anti-inflammatory activity [6], inhibition of the $\alpha$-amylase and $\beta$-glucosidase enzymes [7] and antidiabetic activity [8]. Despite the occurrence of bioactive substances of pharmacological interest, such as carotenoids, flavonoids, triterpenes and cyanogenic glycosides, only about 15 Pouteria species have been investigated from a chemical point of view [5] [9] [10].

Pouteria caimito (abiu) is a fruit species belonging to the Sapotaceae family with a probable centre of origin in the Peruvian Amazon. The fruits and leaves of $P$. caimito are used in folk medicine in the treatment of coughs, bronchitis and diarrhoea [11]. Some studies report the pharmacological potential of this species, such as antioxidant activity [12] and inhibition of $\alpha$-amylase and $\beta$-glucosidase enzymes, which are therapeutic targets in the search for new drugs for the treatment of diabetes [13]. The phytochemical study of $P$. caimito is of great importance, since there are few reports in the literature involving this species. The phytochemical study of the benzene extract of $P$. caimito fruits led to the isolation of $\alpha$-amirin, lupeol, erythrodiol and dammarenediol. Taraxerol, taraxerol acetate, taraxerone and $\beta$-sitosterol were isolated from the stems of this plant [14]. In addition to the hexane extract from the leaves, spinasterol was isolated [5]. Continuing our search for antioxidant substances [15] [16] [17] in plant species of the Brazilian flora, we describe in this work, the chemical study and evaluation of the antioxidant activity of extracts from the leaves of $P$. caimito collected in the Tocantins state, Brazil.

\section{Material and Methods}

\subsection{Materials}

All the chemicals and reagents used in this study were of analytical grade. For thin layer chromatography (CCD), silica gel PF254 plates (Whatman plc, UK) were used, which were observed under UV light $254 \mathrm{~nm}$ and developed with solutions of ferric chloride and the Liebermann-Burchard reagent, followed by heating. Chromatographic column separations (CC) were performed using silica gel 60 (70 - 230 mesh, Vetec, Brazil).

\subsection{Preparation of Extract and Fractions}

Leaves of $P$. caimito were collected on the campus of the Federal University of Tocantins, Gurupi, Tocantins, Brazil. An exsicta was deposited in the herbarium HUTO-UNITINS. Dry leaves (23.0 g) were comminute and extracted with EtOH 
by maceration at room temperature. The resulting solution after filtration was concentrated under reduced pressure to give the crude extract in EtOH (PFE, $3.8 \mathrm{~g}$ ). Part of the PFE extract (3.5 g) was solubilised in a $\mathrm{MeOH} / \mathrm{H}_{2} \mathrm{O}$ solution (7:3) and submitted to liquid/liquid partition to yield the fractions in n-hexane ( $\mathrm{PFH}, 0.9$ g) and AcOEt (PFAE, $1.3 \mathrm{~g}$ ), respectively.

\subsection{Phytochemical Prospecting}

The phytochemical screening of leaf extracts and fractions was assessed by standard phytochemical methods [18]. Phytochemical screening was carried out by the qualitative chemical composition of leaf extracts using different solvents and using colour change, foaming and precipitate to identify the major natural chemical groups, such as tannins, saponins, flavonoids, catechins, alkaloids, xanthones, triterpenes and steroids. General reactions in this analysis revealed the presence or absence of these classes of compounds in the tested leaf extracts.

\subsection{Separation and Identification of Chemical Constituents}

Part of the ethyl acetate fraction (PFAE, $1.0 \mathrm{~g}$ ) was subjected to fractionation using silica gel column chromatography with hexane, chloroform, ethyl acetate and methanol in isocratic mode as eluents. The four sub-fractions obtained were analysed by thin layer chromatography. The sub-fractions eluted with chloroform and ethyl acetate were selected for analysis by ultra-high performance liquid chromatography (UPLC) with a photodiode array detector (PDA) coupled to quadrupole time-of-flight mass spectrometry (QTOF-MS) to obtain the chemical profile, which allowed the identification of triterpenes, namely, euscaphic acid (1), hyptadienic acid (2), betulinic acid (3), ursolic acid (4), oleanolic acid (5), $3 \beta$-( $O$-p-coumaroyl)-alphitolic acid (6), $3 \beta$-( $O$-p-coumaroyl)-maslinic acid (7) and $3 \beta$-(O-p-coumaroyl)-2-hydroxy-urs-12-en-28-oic acid (8).

\subsection{Qualitative UPLC-QTOF-MS Analysis}

Chromatographic separation of compounds was performed on an ACQUITY UPLC system (Waters, Milford, MA, USA) with a conditioned auto sampler at $4^{\circ} \mathrm{C}$, using an Acquity BEH C18 column $(50 \mathrm{~mm} \times 2.1 \mathrm{~mm}$ i.d., $1.7 \mu \mathrm{m}$ particle size) (Waters, Milford, MA, USA). The column temperature was maintained at $40^{\circ} \mathrm{C}$. The used mobile phase was water with $0.1 \%$ formic acid in water (solvent A) and acetonitrile (solvent B), which was pumped at a flow rate of $0.4 \mathrm{ml} \cdot \mathrm{min}^{-1}$. The gradient elution program was as follows: 0 - $5 \mathrm{~min}, 5 \%-10 \% \mathrm{~B} ; 5-9 \mathrm{~min}$, $10 \%-95 \%$ B. The injection volume was $10 \mu \mathrm{l}$. MS analysis was performed on a Xevo G2 QTOF (Waters MS Technologies, Manchester, UK). Source conditions as follows: capillary voltage, $2.0 \mathrm{kV}$; sample cone, source temperature, $100^{\circ} \mathrm{C}$; desolvation temperature $250^{\circ} \mathrm{C}$; cone gas flow rate $20 \mathrm{l} \cdot \mathrm{h}^{-1}$; desolvation gas $\left(\mathrm{N}_{2}\right)$ flow rate $600 \mathrm{l} \cdot \mathrm{h}^{-1}$. All analyses were performed using a lockspray, which ensured accuracy and reproducibility. Leucine enkephalin $\left(5 \mathrm{ng} \cdot \mathrm{ml}^{-1}\right)$ was used as a reference compound to calibrate mass spectrometers during analysis and intro- 
duced by a lockspray at $10 \mu \mathrm{l} \cdot \mathrm{min}^{-1}$ for accurate mass acquisition. All the acquisition and analysis of data were controlled using Waters MassLynx v 4.1 software.

\subsection{Antioxidant Activity}

\subsubsection{Determination of Total Phenolic Content}

The total phenolic content determined the modified Folin-Denis method [19]. Briefly, $0.5 \mathrm{ml}$ of the extract $\left(1.0 \mathrm{mg} \cdot \mathrm{ml}^{-1}\right.$ in methanol) was mixed with $2.5 \mathrm{ml}$ of the Folin-Denis reagent, and after $5 \mathrm{~min}, 2 \mathrm{ml}$ of a $14 \%$ sodium carbonate $\left(\mathrm{Na}_{2} \mathrm{CO}_{3}\right)$ solution was added. After incubation at room temperature for $2 \mathrm{~h}$, the absorbance of the reaction mixture was measured at $760 \mathrm{~nm}$ (T60 UV-Visible Spectrophotometer, PG instruments, UK) against a methanol blank. A standard curve was constructed using gallic acid as a reference substance. The total phenolic content expressed in gallic acid equivalents ( $\mathrm{mg} \mathrm{GAE} \mathrm{g}^{-1}$ of extract).

\subsubsection{2,2-Diphenyl-1-Picrylhydrazyl (DPPH) Assay}

The scavenging activity for the radical DPPH was measured as described by Zhang and Hamauzu (2004) [20]. A volume of $2.7 \mathrm{ml}$ of a $23.6 \mu \mathrm{g} \cdot \mathrm{ml}^{-1} \mathrm{DPPH}$ methanolic solution was added to $0.3 \mathrm{ml}$ of various concentrations of extracts (100 to $1200 \mu \mathrm{g} \cdot \mathrm{ml}^{-1}$ in methanol) or ascorbic acid standard $\left(0.5\right.$ at $4 \mu \mathrm{g} \cdot \mathrm{ml}^{-1}$ in methanol). The mixtures were kept in the dark for $30 \mathrm{~min}$ at room temperature, and the absorbance of the remaining DPPH was determined at $517 \mathrm{~nm}$ (T60 UV-Visible Spectrophotometer, PG instruments, UK). A $3.0 \mathrm{ml}$ of methanol was used as a blank, and a mixture of $2.7 \mathrm{ml}$ of DPPH solution with $0.3 \mathrm{ml}$ of methanol was used as a negative control. The radical scavenging activity was calculated as a percentage of DPPH discoloration using Equation (1):

$\mathrm{AA} \%=($ the absorbance of the negative control - the absorbance of an extract or standard/the absorbance of the negative control $) \times 100$

where AA\% is the inhibition percentage. The effective concentration providing $50 \%$ inhibition $\left(\mathrm{EC}_{50}\right)$ was calculated from the graph of scavenging effect percentage against extract or ascorbic acid standard concentration.

\subsection{Statistical Analysis}

Each experiment was performed at least three times. All values are expressed as means \pm standard deviation. All statistical analyses were performed with GraphPad Prism 5 DEMO.

\section{Results and Discussion}

\subsection{Phytochemical Prospecting and Peak Assignment by UPLC-QTOF-MS}

In phytochemical prospecting, it was verified that only triterpenes and steroids were present in the hexane fraction (PFH) of leaves of $P$. caimito. However, triterpenes, steroids, saponins, flavonoids and catechins were detected in the 
ethanolic extract (PFE) and the ethyl acetate fraction (PFAE) (Table 1). The study evidenced the presence of secondary metabolites, which may be related to the medicinal properties of $P$. caimito leaves.

UPLC-PDA-MS is a newly developed technique that provides a great amount of information rapidly and efficiently compared with other techniques. The high selectivity and sensitivity of UPLC-QTOF-MS makes it a widely applied technique in quantitative and qualitative analysis, as well as in metabolite analysis and the identification of complex compounds in natural products [21].

Table 2 lists the tentatively identified compounds in PFAE. A total of eight compounds were identified by UPLC-QTOF-MS (Figure 1) based on database interrogation and references, as shown in Figure 2. Peaks 1, 2, 3, 4, 5, 6, 7 and 8 were identified as euscaphic acid, hyptadienic acid, betulinic acid, oleanolic acid, ursolic acid, $3 \beta$-(O-p-coumaroyl)-alphitolic acid, $3 \beta$-(O-p-coumaroyl)-maslinic acid and $3 \beta$-(O-p-coumaroyl)-2-hydroxy-urs-12-en-28-oic acid, respectively, based on UV, MS and MS/MS fragment ions [21] [22]. This is the first report of the occurrence of triterpenes 1, 2, 6, 7 and 8 in the Sapotaceae family. Euscaphic acid (1) isolated from Cecropalyratiloba presented cytotoxic activity against leukemic cell lines [23] and $3 \beta$-(O-p-coumaroyl)-alphitolic acid (6) leads to apoptotic cell death in human leukemia cells [24]. Betulinic acid (3) was previously identified in the species $P$. gardnerii, P. tomentosa and P. torta [5]. Oleanolic acid (4) was isolated from $P$. gardnerri [5]. Ursolic acid (5) was isolated from the species $P$. gardnerii, $P$. venosa, $P$. tomentosa and $P$. torta [5]. The triterpenes derived from oleanans and ursans present antitumor, anti-inflammatory and antioxidant activities [25]. Thus, the identification of these triterpenes in leaf extracts of $P$. caimito may contribute to the pharmacological potential of this species.

Table 1. Phytochemical prospecting of extracts and fractions of $P$. caimito leaves.

\begin{tabular}{cccc}
\hline Constituents & $\begin{array}{c}\text { extract } \\
\text { in ethanol }\end{array}$ & $\begin{array}{c}\text { fraction } \\
\text { in hexane }\end{array}$ & $\begin{array}{c}\text { fraction in } \\
\text { ethyl acetate }\end{array}$ \\
\hline $\begin{array}{c}\text { Triterpenes/steroids } \\
\text { Saponins }\end{array}$ & + & + & + \\
Alkaloids & + & - & + \\
Tannins & - & - & - \\
Flavones, flavonols and xanthones & + & - & + \\
Chalcones and auronas & - & - & - \\
Flavanonols & - & - & - \\
Leucoantocianidines & - & - & + \\
Cathechins & - & - & - \\
Flavanones & - & - & -
\end{tabular}


Table 2. Identified compounds in the extracts from leaves of $P$. caimito.

\begin{tabular}{|c|c|c|c|c|c|c|}
\hline \multirow{2}{*}{$\begin{array}{c}\text { Peak } \\
\text { No. } \\
1\end{array}$} & \multirow{2}{*}{$\begin{array}{c}\begin{array}{c}\mathrm{T}_{\mathrm{R}} \\
(\mathrm{min})\end{array} \\
2.69\end{array}$} & \multirow{2}{*}{$\begin{array}{c}\begin{array}{c}\text { Assigned } \\
\text { identity }\end{array} \\
\begin{array}{c}\text { euscaphic } \\
\text { acid }\end{array}\end{array}$} & \multicolumn{3}{|c|}{$\begin{array}{c}{[\mathrm{M}-\mathrm{H}]^{-} \mathrm{m} / \mathrm{z}} \\
\text { Meanmeasured Theorical ppm } \\
\text { mass (Da) exact mass (Da) }\end{array}$} & \multirow{2}{*}{$\begin{array}{c}\text { References } \\
{[21]}\end{array}$} \\
\hline & & & 487.3417 & 487.3423 & -1.2 & \\
\hline 2 & 2.75 & $\begin{array}{c}\text { hyptadienic } \\
\text { acid }\end{array}$ & 469.3327 & 469.3318 & 1.9 & [21] \\
\hline 3 & 4.64 & $\begin{array}{c}\text { betulinic } \\
\text { acid }\end{array}$ & 455.3520 & 455.3525 & -1.1 & {$[21]$} \\
\hline 4 & 4.66 & $\begin{array}{c}\text { oleanolic } \\
\text { acid }\end{array}$ & 455.3518 & 455.3525 & -1.5 & [21] \\
\hline 5 & 4.68 & $\begin{array}{l}\text { ursolic } \\
\text { acid }\end{array}$ & 455.3528 & 455.3525 & 0.6 & [21] \\
\hline 6 & 5.75 & $3 \beta-O-(p$-coumaroyl $)$-maslinicacid & 617.3823 & 617.3842 & -3.0 & [22] \\
\hline 7 & 5.89 & $3 \beta$-O-(p-coumaroyl)-maslinic acid & 617.3820 & 617.3842 & -3.6 & [22] \\
\hline 8 & 5.98 & $3 \beta$-O-(p-coumaroyl)-2-hydroxy-urs-12-en-28-oic acid & 617.3819 & 617.3842 & -3.7 & [21] \\
\hline
\end{tabular}

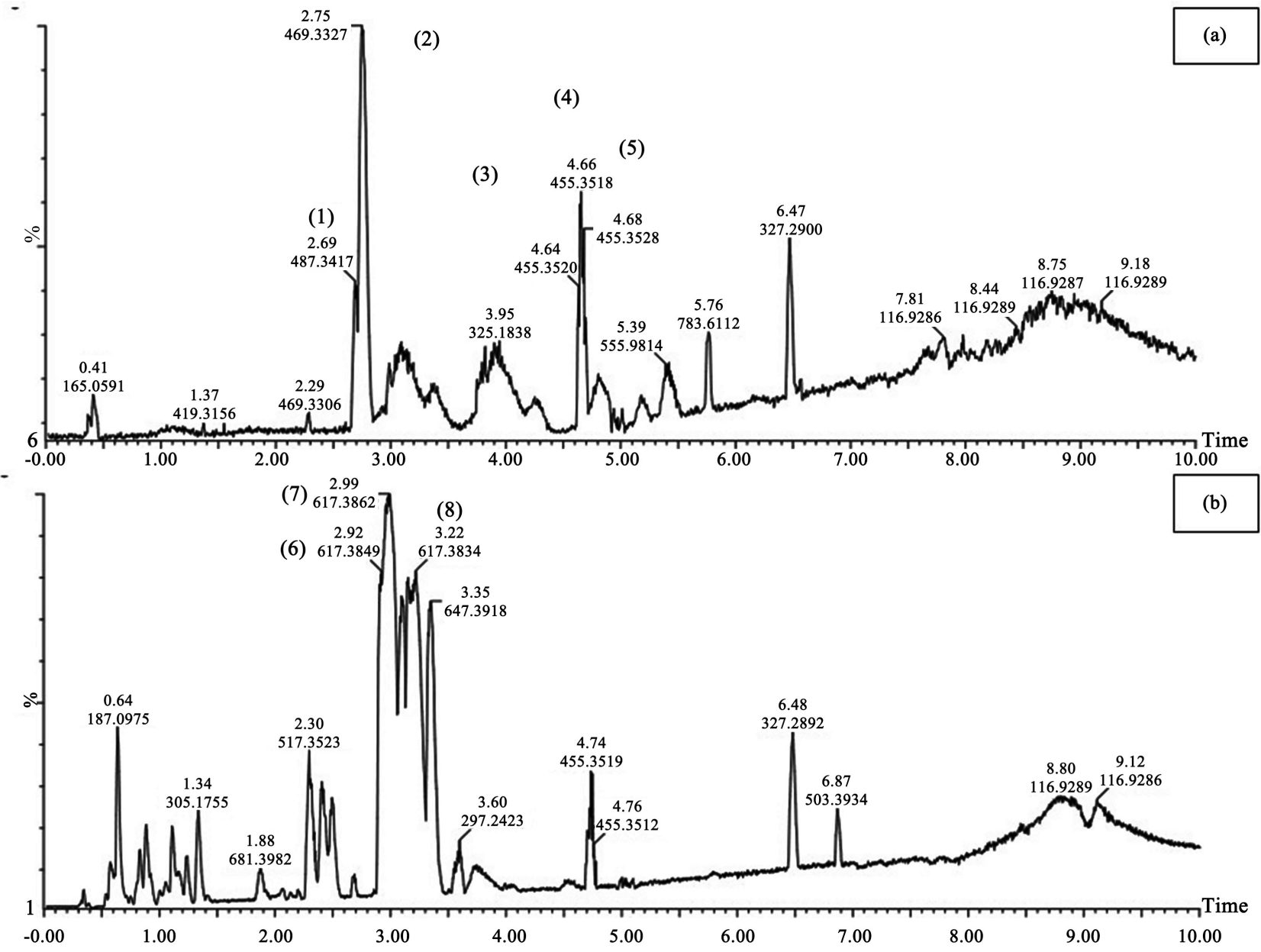

Figure 1. The total current ion chromatograms (UPLC-QTOF-MS) of the PFAE fraction of $P$. caimito leaves in negative ion mode: sub-fractions chloroform (a) and ethyl acetate (b). 

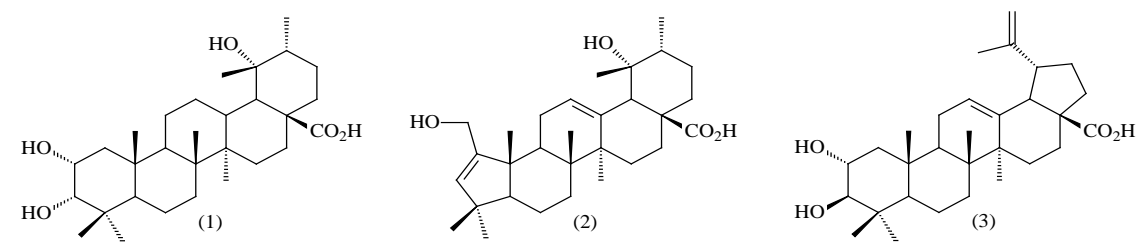<smiles>CC1(C)CCC2(O)CC[C@]3(C(=O)O)C(CCC4C5CCC(O)C(C)(C)C5CCC43C)C2C1</smiles>

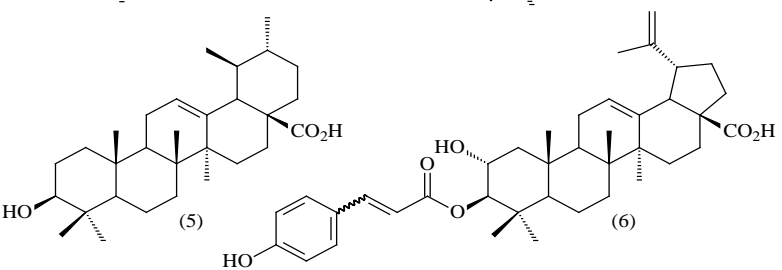

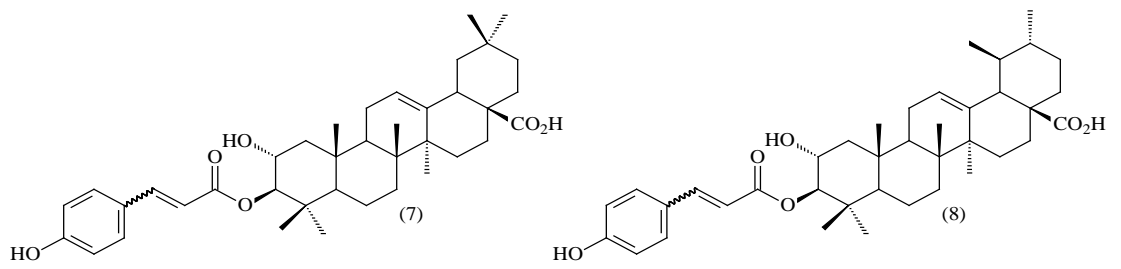

Figure 2. Structures of substances identified in extracts of $P$. caimito leaves.

Table 3. Antioxidant activityof extracts of $P$. caimito measured by total phenolic content and DPPH assay.

\begin{tabular}{ccc}
\hline $\begin{array}{c}\text { Extracts and } \\
\text { standard substance }\end{array}$ & $\begin{array}{c}\text { Total phenolic content } \\
\left(\mathrm{mg} \mathrm{GAE} \mathrm{g}^{-1} \text { extract }\right)\end{array}$ & $\begin{array}{c}\mathrm{DPPH} \\
\mathrm{EC}_{50}\end{array}$ \\
\hline PFE & $10.6 \pm 0.1$ & $299.4 \pm 1.5$ \\
PFH & $7.7 \pm 0.6$ & $1439.4 \pm 2.7$ \\
PFAE & $11.4 \pm 0.3$ & $391.8 \pm 0.9$ \\
Ascorbic acid & - & $2.05 \pm 0.02$ \\
\hline
\end{tabular}

\subsection{Antioxidant Activity}

The Folin-Denis assay is a fast and simple method for determining the phenolic compound contents in plant samples. The fraction in AcOEt of the leaves of $P$. caimito presented the highest phenolic content in comparison to the other fractions of the leaves analysed $\left(11.37 \pm 0.3 \mathrm{mg} \mathrm{GAE} \mathrm{g}^{-1}\right)$, followed by the extract in EtOH (Table 3). Extracts from leaves of $P$. caimito presented total phenolic contents similar to other species of this genus [12] [26] [27].

The scavenging activity for free radicals of DPPH

(1,1-Diphenyl-2-picrylhydrazyl) has widely been used to evaluate the antioxidant activity of natural products from plant and natural sources [28]. The results of the DPPH radical scavenging activity of the extract, fractions and ascorbic acid are presented in Table 3. PFE and PFAE had higher antioxidant activity than PFH ( $\mathrm{p}<0.05)$, but the antioxidant activity was significantly lower than the standard ascorbic acid $(\mathrm{p}<0.05)$. The ethanol extract and ethyl acetate fraction showed a higher DPPH radical scavenging activity than that reported for the acetone extract of the pulp of $P$. caimito [12]. Part of the observed antioxidant activity can be attributed to phenolic compounds detected by the phytochemical 
analysis and triterpenes identified by UPLC-QTOF-MS.

\section{Conclusion}

The phytochemical screening and antioxidant activity of medicinal plants are very important in identifying new sources of therapeutically and industrially important compounds. The analysis of the ethyl acetate fraction (PFAE) by UPLC-QTOF-MS allowed the identification of eight triterpenes that are being reported for the first time in $P$. caimito. In addition, the in vitro antioxidant activity of the extract and fractions obtained from the leaves of $P$. caimito using the DPPH assay is reported.

\section{Acknowledgements}

The authors thank Capes, CNPq, FACEPE and FAPERJ for financial support.

\section{Conflicts of Interest}

The authors declare no conflicts of interest regarding the publication of this paper.

\section{References}

[1] Triono, T., Brown, A.H.D., West, J.G. and Crisp, M.D. (2007) A Phylogeny of Pouteria (Sapotaceae) from Malesia and Australasia. Australian Systematic Botany, 20, 107-118. https://doi.org/10.1071/SB06011

[2] Pennington, T.D. (1990) Flora Neotropica: Sapotaceae. The New York Botanical Garden, New York.

[3] Carneiro, C.E. and Almeida Junior, E.B. (2010) Sapotaceae. In: Lista de Espécies da Flora do Brasil, JardimBotânico do Rio de Janeiro, Rio de Janeiro.

[4] Rodrigues, P.M., Dutra Gomes, J.V., Jamal, C.M., Cunha Neto, Á., Santos, M.L., Fagg, C.W., Fonseca-Bazzo, Y.M., Magalhães, P.O., de Sales, P.M. and Silveira, D. (2017) Triterpenes from Pouteria ramiflora (Mart.) Radlk. Leaves (Sapotaceae). Food and Chemical Toxicology, 109, 1063-1068. https://doi.org/10.1016/j.fct.2017.05.026

[5] Silva, C.A.M., Simeoni, L.A. and Silveira, D. (2009) Genus Pouteria: Chemistry and Biological Activity. Brazilian Journal of Pharmacognosy, 19, 501-509. https://doi.org/10.1590/S0102-695X2009000300025

[6] Fontes Junior, E.A., Souza, P.J.C., Nascimento, J.L.M., Santos, S.N., Espíndola, L.S. and Ferreira, V.M.M. (2009) Antinociceptive and Antiinflammatory Properties of the Ethanolic Extract of Pouteria ramiflora Roots. Latin American Journal of Pharmacy, 28, 812-818.

[7] Sales, P.M., Souza, P.M., Dartora, M., Resck, I.S., Simeoni, L.A., Fonseca-Bazzo, Y. M., Magalhães, P.O. and Silveira, D. (2017) Pouteria torta Epicarp as a Useful Source of $\alpha$-Amylase Inhibitor in the Control of Type 2 Diabetes. Food and Chemical Toxicology, 109, 962-969. https://doi.org/10.1016/j.fct.2017.03.015

[8] Prabhu, S., Vinodhini, S., Elanchezhiyan, C. and Rajeswari, D. (2018) Evaluation of Antidiabetic Activity of Biologically Synthesized Silver Nanoparticles Using Pouteria sapota in Streptozotocin-Induced Diabetic Rats. Journal of Diabetes, 10, 28-42. https://doi.org/10.1111/1753-0407.12554 
[9] Gulyás-Fekete, G., Murillo, E., Kurtán, T., Papp, T., Illyés, T.-Z., Drahos, L., Visy, J., Agósc, A., Turcsi, E. and Deli, J. (2013) Cryptocapsinepoxide-Type Carotenoids from Red Mamey, Pouteria sapota. Journal of Natural Products, 76, 607-614. https://doi.org/10.1111/1753-0407.12554

[10] Murillo, E., Mosquera, Y., Kurtán, T., Gulyás-Fekete, G., Nagy, V. and Deli, J. (2012) Isolation and Characterization of Novel Capsorubin-Like Carotenoids from the Red Mamey (Pouteria sapota). Helvetica Chimica Acta, 95, 983-988. https://doi.org/10.1002/hlca.201100493

[11] Boscolo, O.H. and Valle, L.S. (2008) Plantas de uso medicinal em Quissamã, Rio de Janeiro, Brasil. Iheringia Série Botânica, 63, 263-277.

[12] Virgolin, L.B., Seixas, F.R.F. and Janzantti, N.S. (2017) Composition, Content of Bioactive Compounds, and Antioxidant Activity of Fruit Pulps from the Brazilian Amazon Biome. Revista Agropecuária Brasileira, 52, 933-941. https://doi.org/10.1590/s0100-204x2017001000013

[13] Souza, P.M., Sales, P.M., Simeoni, L.A., Silva, E.C., Silveira, D. and Magalhães, P.O. (2012) Inhibitory Activity of Alpha-Amylase and Alpha-Glucosidase by Plant Extracts from the Brazilian Cerrado. Planta Medica, 78, 393-399. https://doi.org/10.1055/s-0031-1280404

[14] Pellicciari, R., Ardon, A. and Bellavita, V. (1972) Triterpenes from Pouteria caimito. Planta Medica, 22, 196-200. https://doi.org/10.1055/s-0028-1099603

[15] Carvalho Junior, A.R., Gomes, G.A., Ferreira, R.O. and Carvalho, M.G. (2014) Constituintesquímicos e atividadeantioxidante de folhas e galhos de Eugenia copacabanensis Kiaersk (Myrtaceae). Química Nova, 37, 477-482.

[16] Ferreira, R.O., Carvalho Junior, A.R., Silva, T.M.G., Castro, R.N., Silva, T.M.S. and Carvalho, M.G. (2014) Distribution of Metabolites in Galled and Non-Galled Leaves of Clusialanceolata and Its Antioxidant Activity. Brazilian Journal of Pharmacognosy, 24, 617-625.

[17] Ferreira, R.O., Carvalho Junior, A.R., Riger, C.J., Castro, R.N., Silva, T.M.S. and Carvalho, M.G. (2016) Constituintesquímicos e atividadeantioxidante in Vivo de flavonoidesisolados de Clusialanceolata (Clusiaceae). Química Nova, 39, 1093-1097. https://doi.org/10.1016/j.bjp.2014.11.005

[18] Matos, F.J. (1997) Introdução à fitoquímica experimental. 2nd Edition, Edições UFC, Fortaleza.

[19] Singleton, V.L., Orthorfer, R. and Lamuela-Raventós, R.M. (1999) Analysis of Total Phenols and Other Oxidation Substrates and Antioxidants by Means of Follin-Ciocateu Reagent. Methods in Enzimology, 299, 152-178. https://doi.org/10.1016/S0076-6879(99)99017-1

[20] Zhang, D. and Hamauzu, Y. (2004) Phenolics, Ascorbic Acid, Carotenoids and Antioxidant Activity of Broccoli and Their Changes during Conventional and Microwave Cooking. Food Chemistry, 88, 503-509. https://doi.org/10.1016/j.foodchem.2004.01.065

[21] Wu, L., Jiang, X., Huang, L. and Chen, S. (2013) Processing Technology Investigation of Loquat (Eriobotrya japonica) Leaf by Ultra-Performance Liquid Chromatography-Quadrupole Time-of-Flight Mass Spectrometry Combined with Chemometrics. PLOS ONE, 8, e64178.

[22] Lee, S.-M., Park, J.-G., Lee, Y.-H., Lee, C.-G., Min, B.-S., Kim, J.-H. and Lee, H.-K. (2004) Anti-Complementary Activity of Triterpenoides from Fruits of Zizyphusjujuba. Biological Pharmaceutical Bulletin, 27, 1883-1886. https://doi.org/10.1248/bpb.27.1883 
[23] Rocha, G.G., Simões, M., Lúcio, K.A., Oliveira, R.R., Kaplan, M.A.C. and Gattass, C.R. (2007) Natural Triterpenoids from Cecropialyratiloba Are Cy Totoxic to Both Sensitive and Multidrug Resistant Leukemia Cell Lines. Bioorganic Medicinal Chemistry, 15, 7355-7360. https://doi.org/10.1016/j.bmc.2007.07.020

[24] Mitsuhashi, Y., Furusawa, Y., Aradate, T., Zhao, Q.-L., Moniruzzaman, R., Kanamori, M., Noguchi, K. and Kondo, T. ((2017) 3-O-Trans-p-Coumaroyl Alphitolic Acid, a Triterpenoid from Zizyphus jujuba, Leads to Apoptotic Cell Death in Human Leukemia Cells through Reactive Oxygen Species Production and Activation of the Unfolded Protein Response. PLoS ONE, 12, e 0183712.

https://doi.org/10.1371/journal.pone.0183712

[25] Vechia, L.D., Gnoatto, S.C.B. and Gosmann, G. (2009) Derivadosoleananos e ursanos e suaimportâncianadescoberta de novosfármacos com atividadeantitumoral, anti-inflamatória e antioxidante. Química Nova, 32, 1245-1252.

https://doi.org/10.1590/S0100-40422009000500031

[26] Fuentealba, C., Gálvez, L., Cobos, A., Olaeta, J.A., Defilippi, B.G., Chirinos R, Campos, D. and Pedreschi, R. (2016) Characterization of Main Primary and Secondary Metabolites and in Vitro Antioxidant and Antihyperglycemic Properties in the Mesocarp of three Biotypes of Pouterialucuma. Food Chemistry, 190, 403-411. https://doi.org/10.1016/j.foodchem.2015.05.111

[27] Yahia, E.M., Gutiérrez-Orozco, F. and Arvizu-de Leon, C. (2011) Phytochemical and Antioxidant Characterization of Mamey (Pouteria sapota Jacq. H.E. Moore \& Stearn) Fruit. Food Research International, 44, 2175-2181. https://doi.org/10.1016/j.foodres.2010.11.029

[28] Pavithra, K. and Vadivukkarasi, S. (2015) Evaluation of Free Radical Scavenging Activity of Various Extracts of Leaves from Kedrostis foetidissima (Jacq.) Cogn. Food Science and Human Wellness, 4, 42-46. https://doi.org/10.1016/j.fshw.2015.02.001 